\title{
Graffiti Inside Jordanian Public Transport Vehicles
}

\section{Графіті в суспільному транспорті Йорданії}

\author{
Ghada Al Karazoun \\ Ph.D., Candidate \\ Jihad M. Hamdan \\ Ph.D. (Linguistics), \\ Professor
}

\author{
Гхада Аль Каразоун \\ доктор філософії (Ph.D.)
}

E-mail: ghadaalkarazoun@gmail.com

https://orcid.org/0000-0003-4781-1508

Джихад М. Хамдан

доктор філософії в галузі лінгвістики

\author{
E-mail: j.hamdan@ju.edu.jo \\ https://orcid.org/0000-0002-8952-6310 \\ Researcher ID 11808 \\ Scopus Author ID: 10142472400
}

The University of Jordan

Queen Rania Str., Amman, Jordan, 11942
Йорданський університет

$\triangle$ вул. Королеви Ранії, Аман, Йорданія, 11942

Original manuscript received September 04, 2020

Revised manuscript accepted October 07, 2021

\begin{abstract}
Purpose. The study reported here aims to investigate the commonest communicative categories and subcategories of graffiti written inside Jordanian public transport vehicles.

Method. The researchers collected 1,410 tokens of graffiti from six Jordanian cities, viz., Amman, Madaba, Irbid, Zarqa, Salt, and Jerash. The data which were collected from public transport vehicles included 1000 handwritten graffiti tokens and 410 custom-made stickers. Specifically, the data were collected from large and small buses as well as service and yellow taxis that lined up in main bus stations and bus stops available in front of hospitals, universities, malls and close to traffic circles. Then the categories and subcategories of graffiti were identified on the basis of their content.
\end{abstract}


Results. The analysis reveals eight communicative categories, viz., personal, interpersonal, philosophical, religious, offensive, political, humorous, and sports.

The analysis also reveals thirteen subcategories, viz., naming and self-identification, self-appraisal, love and familial relationships, philosophical perspectives, the ethics of transport, decline of morals, expressions of Islamic faith, supplication, preaches, protection from the envious eye, territorial and tribal affiliation.

Conclusions. The study concludes that a host of societal concerns and individuals' feelings and thoughts are transmitted through the discourse of graffiti. The passengers and drivers have expressed their self-concentration, philosophical views, affiliation with territories and tribes, hostility and anger to individuals and groups, and allegiance to religion beliefs and traditions. The study also concludes that there are socio-psychological motives that drive writing graffiti, viz., identify oneself, release emotions, criticize individuals and groups, reveal pride and admiration, advertise goods and promote business, search for contacts, post messages for the public, express attachment to educational institutions, document the occurrence of a particular occasion. The study recommends that graffiti written inside public transport vehicles in other Arab countries be examined. Thus, one could examine to what extent the communicative categories and subcategories of graffiti along with its sociopsychological tend to show a pan-Arab base.

Key words: category, graffiti, interpersonal, psycholinguistics, religion, selfconcentration.

\section{Introduction}

Language and society are interrelated. Language carries the values and morals by which people come to perceive themselves and their place in the world. In return, how people perceive themselves through language affects how they look at societies, politics, relationships, and the world. The relationship between language and society puts forward a field of study called 'Sociolinguistics'. It aims to gain a better understanding of the structure of language and how language functions in communication (Wardhaugh, 2006: 11-13). However, the study of conscious use of language as is the case in producing and interacting with graffiti falls within the scope of psycholinguistics.

People often use spoken utterances and written scripts to communicate. Writing is one of humans' greatest inventions. People have been writing on the surfaces of public spaces and private properties for millennia, and what is written or inscribed is called 'graffiti'. According to D'Angelo (1974: 173), graffiti includes casual drawings, inscriptions, 
slogans, and/or markings which appear on billboards, fences, and walls, among others. Taylor (1999: 290-291) contends that graffiti is composed of thoughts and feelings translated into short written phrases or visual codes with vivid meanings inspired from the society, and accordingly it is a societal product.

Language is viewed as a social construct; it is a system for converting preexisting ideas into sounds, gestures, or written symbols to be passed onto the minds of others (Mostafa, 2018: 66). It is assumed that written language is a reflection of spoken language. It pictures the mental images and representations transmitted by communicators into written units. In other words, written language delivers the forms and content of spoken utterances and mental thoughts through written forms. Thus, it functions as a mirror of mind and a tool for the expression of thought (Gleitman \& Papafragou, 2005: 634-635). Durmuller (1988: 278-280) posits that graffiti is an effective means in which the contents of individual minds as well as perceptions and memories associated with certain groups and cultures are conveyed through written utterances, phrase, or sentences. Put another way, graffiti is a reflection of the content of language consciousness of ordinary people. Therefore, it helps psycholinguists reveal clues into people's cognitive aspects of thinking and even ways of knowing. It also helps sociolinguistics get hints about people's personal and cultural experiences, habits, and behavior.

The anonymity of graffiti writers invokes them to speak about the unspeakable and open up without borders. Hence, graffiti is viewed as a discourse that does not adhere to any protocol or restrictions. Fraser (1980: 259) claims that it "is a chance to vent frustrations-to say things you wouldn't dare speak up about". It can be jocular or satirical, esthetic or coarse, pure or bawdy, entertaining or insulting to one's feelings. However, MacGillivray and Curwen (2007: 358-360) believe that not all graffiti writers wish to remain anonymous. In fact, the explicit mention of the graffiti writers' names or groups' names on public places is probably meant to gain fame and recognition.

Blume (1985: 144-145) maintains that people write graffiti for the psychological need to communicate and express thoughts. He claims that there are socio-psychological motives that drive writing graffiti, viz., express oneself, document group membership, criticize and protest, mark out territories, and search for contacts, among others. Von Polenz (cited in Blume 1985: 145) highlights the cognitive function 
of language. He reports that people who write about perceptions, memories, plans, etc. without addressing a particular partner reveal part of their cognitive thinking and mental processing. Lapyai (2003: 39) proposes other psychological reasons that motivate writing graffiti such as delivering pleasure, releasing feelings, constructing one's identity, insulting and showing hostility, revealing philosophical opinions, giving advice, etc.

Road transport vehicles in Jordan include buses, taxis, airport taxis, and vehicles that use smart applications (Ministry of Tourism and Antiquities, 2021). The phenomenon of writing graffiti inside Jordanian public transport vehicles, particularly buses and taxis abounds. Based on the researchers' notes, drivers and passengers of such vehicles often write on their interior surfaces that allow for visibility. For example, they tend to write on the seats, ceilings, glove compartments, sun visors, and doors. One may find abbreviations, acronyms, numbers, short phrases, sentences, Quranic verses, and/or dialogues. To write graffiti, people use ink pens, wax colors, magic markers, correction pens, paint markers, and sharp tools such as knives. Themes of graffiti written inside Jordanian public transport vehicles range from funny expressions to odd ones that provoke one's detestation and repugnance. Other themes address political beliefs, philosophical perspectives, religious affiliations, social relationships, satirical comments, etc.

Studies in the Jordanian context that investigate graffiti written on vehicles are not many. For example, Hazaymeh (2007) states that writing on vehicles is a functional phenomenon related to Jordanians' traditions derived from Islamic history. The study reveals that different socio-psychological functions are conveyed such as declaring religious affiliations and beliefs, revealing feelings and emotions, advising and/ or warning others, demonstrating loyalty and belonging, naming self and others, marking territories and occupation, and expressing fame and self-assertion, among others. Alkurdi (2016) indicates that writing on vehicles expresses themes that relate, envy, warning, pride, desperation, religion, love, wisdom, etc. Jaradat's study (2016) on bumper stickers reveals social, economic, and philosophical themes. Darwish and Al Rousan (2019) demonstrate that the themes of inscriptions on vehicles are associated with religion, love, philosophy, advertisement, futility and fun, patriotism, etc. 
While none of the former researchers reported what vehicles (e.g. public transport, military, or campaign) are examined in their studies, El-Nashar and Nayef (2016) examine graffiti written on Egyptian trucks, microbuses, taxi-cabs, rickshaws. The study highlights four thematic categories, viz., religious, personal, social and philosophical, and political. Hafez (2020) maintains that bumper stickers on Egyptian private vehicles, taxis and service microbuses are mainly about selfidentification. Other themes include hostility and recklessness, driving instructions, romance, envy, religion, and humor, among others.

In the non-Arab setting, Date-Bah (1980) reports that the inscriptions written on and inside Ghanaian commercial vehicles classify into different thematic categories, viz., appreciation of generous kinsmen, religious or supernatural beliefs, views about life and the world, political consciousness, personal idols, etc. Case's (1992) study of bumper stickers and car signs displayed on American private vehicles reveals six thematic categories, viz., ideological/political, safety/public service, philosophical, commercial products, self-identifying expressions, and the other. Divsalar and Nemati (2012) claim that written expressions on vehicles address some aspects of immoral behavior in the Iranian society. Hasrati, Street and Habibi (2016) maintain that graffiti written on Iranian vehicles reveals themes that relate to religion, humor, pessimism, ethno-graphic identification, etc. Faniran, Ikotun and Oloyede (2019) state that the inscriptions and stickers on Nigerian buses and taxis shed light on themes that relate to religion, morality, advertisement, politics, and humor, among others.

As indicated, studies conducted in the Arab setting (e.g. Alkurdi, 2016; El-Nashar \& Nayef, 2016; Hazaymeh, 2007; Jaradat, 2016) investigate the functions or themes of graffiti written on vehicles. In contrast, the current study investigates the communicative categories and subcategories of graffiti written inside Jordanian public transport vehicles. It also examines the socio-psychological motives behind writing graffiti inside these vehicles. Thus, it fills a gap in the literature, as it may qualify to be the first to address graffiti written (in) and not (on) vehicles. Specifically, the study reported here seeks an answer to the following question: "What are the commonest communicative categories and subcategories of graffiti written inside Jordanian public transport vehicles?". 


\section{Method}

\section{Sample and population}

The population of the current study included all graffiti written inside Jordanian public transport vehicles. A total number of 1, 410 tokens were collected from six Jordanian cities, viz., Amman, Madaba, Irbid, Zarqa, Salt, and Jerash. On average, 230 graffiti tokens were collected from different public transport vehicles in each city. The collected data included 1000 handwritten graffiti tokens and 410 custommade stickers (i.e. stickers inscribed by auto painters).

\section{Adherence to Ethical Standards}

The anonymous writers of the collected graffiti or even those who made vague reference to their identity left their products on the seats and ceilings of the vehicles for the public to see, read, enjoy or even to respond. In fact, they were no longer the owners of their products, and thus there was no research need to look for them and seek their informed consent to use their publicly exposed artefacts. What was more important and probably fell under ethical considerations was to seek the informed consent of the owners/drivers of the targeted public transport vehicles, which the researchers did. Thus, we developed a short form (in Arabic) for this purpose in which it was made clear that the collected data would be analyzed for research purposes only and that neither the identity of the owners/drivers nor their vehicles would be disclosed. By signing the form, the vehicle owners and/or drivers gave their consent to the researchers' entering their vehicles in the absence of passengers to collect the written/inscribed graffiti and publish the results of this research including the publication of related images.

No institutional funding was received during the preparation of this research. Further, the authors did not have any potential conflict of interest that had influenced the writing or content of this research.

\section{Data Collection}

To collect data necessary for the current study, the researchers spent an 8-month period, starting from January 2019 till June 2020, collecting graffiti tokens that were accessible and available from six Jordanian cities. Collecting data from different cities was done to 
achieve variation and avoid repetition. The data were collected from large buses, small buses (Coaster), service taxis, and yellow taxis. The researchers collected graffiti directly from inside these vehicles, and this took different forms. One form was to take notes of the exact graffiti tokens. Another form was to take photos of graffiti to save time. On more than one occasion, the researchers had some conversations with bus conductors and drivers and asked them about the meaning of some graffiti.

Data collection procedures took several steps. First, the researchers collected graffiti from public transport vehicles distributed across town centers of each city. Specifically, the data were collected from buses and taxis that lined up in main bus stations and bus stops available in front of hospitals, universities, malls and close to traffic circles. This was done to collect as many graffiti tokens as possible from places where public transport vehicles park frequently at different times to carry passengers. Second, once the researchers got the drivers' or bus conductors' consent, the researchers took photos of graffiti written inside these vehicles. In case of any hindrance to taking photos such as poor lighting, the researchers took notes of such graffiti to document their observation. Collected data were kept intact in files and did not go under any modifications or corrections.

During data collection, some points were noteworthy to be considered. First, it was difficult for the researchers to figure out the exact number of Jordanian public transport vehicles that were in the main bus stations or close to traffic circles and to count the number of graffiti tokens collected from each vehicle. Moreover, in case that written and pictorial graffiti appeared together, the emphasis was on written graffiti. Another point was about data distribution. It was observed that most graffiti was written inside big and small buses more than service and yellow taxis. This might be related to the fact that the former has larger spaces to write on and stick stickers compared to the limited spaces available inside the latter. The former also transports more passengers than the latter, and this would increase the number of graffiti written as passengers are a source of graffiti.

\section{Data Analysis}

A qualitative content analysis was used to systematically describe the meaning of graffiti by assigning successive parts of texts 
to communicative categories. Elo and Kyngäs (2008: 108) elaborate that when texts are classified into the same categories, the targeted texts share the same meaning or content. The collected tokens were categorized according to their (1) overall intent or subject matter, and (2) word content or meaning, particularly if the overall intent of the targeted graffiti was not reasonably clear. Then the researchers defined the communicative categories of graffiti by naming them and providing a descriptor of what was meant by that name. Some categories and subcategories were adopted from relevant graffiti studies conducted in the Arab context (e.g. Alkurdi, 2016; El-Nashar \& Nayef, 2016; Hazaymeh, 2007) and non-Arab context (e.g. Case, 1992; Faniran et al., 2019; Hasrati et al., 2016). However, it was necessary to create new communicative categories and subcategories on the basis of the nature of the collected data.

A total of eight communicative categories were identified which subclassify into thirteen communicative subcategories. Since some graffiti appeared to be written by different individuals, it was important to identify each graffiti token. Sechrest and Flores (1969: 5) propose three cues such as different handwriting, writing tools, and thematic inconsistency. The researchers considered a four-line poem, for example, a single graffiti token if it is coherent and written with the same writing tool and hand. The identified communicative categories were subjected to a validation process by a panel of jurors from the Hashemite University, a public university located on the outskirts of the city of Zarqa in Jordan. The jurors were three linguists in the Department of English Language and Literature whose native language is Jordanian Spoken Arabic. They were asked to review the categories of graffiti and their descriptors set by the researchers to determine the validity of the identified categories (see table 1). In those cases where there was an initial disagreement, the jurors and the researchers came to a decision after resolving their differences. The number and percentage of each category and subcategory of graffiti were calculated and tabulated to determine the frequency of occurrence of each one (see table 2).

\section{Results and Discussion}

Table 1 shows the communicative categories of graffiti and respective descriptors of what is meant by each communicative category. 
Table 1

Communicative categories of graffiti and their respective descriptors

\begin{tabular}{ll}
\hline Category & Descriptors \\
\hline Personal & $\begin{array}{l}\text { Items that refer to oneself, friends, family and others; } \\
\text { items that refer to one's quality, conduct, character, etc. }\end{array}$ \\
\hline Religious & Items on religion, deity, prophets, etc. \\
\hline Political & Items on political actions, policies, institutions, leadership, etc. \\
\hline Humorous & Items that funny and satirical. \\
\hline $\begin{array}{l}\text { Interpersonal } \\
\text { Relationship }\end{array}$ & Items on how people are socially related with each other. \\
\hline Philosophical & $\begin{array}{l}\text { Items on life, death, the world, people's relations with others, etc.; } \\
\text { items related to ethics, wisdom, morality, etc. }\end{array}$ \\
\hline Sports & Items that refer to names of sports teams or games. \\
\hline Offensive & Items that insult indviduals and/or refer to hard life conditions \\
\hline
\end{tabular}

Table 2 presents the commonest communicative categories and subcategories of graffiti written inside Jordanian public transport vehicles. It also highlights the number and percentage of each category and subcategory.

Table 2

Number and percentage of categories and subcategories of graffiti written inside Jordanian public transport vehicles

\begin{tabular}{lcc}
\hline Categories and Subcategories & No & $\mathbf{\%}$ \\
\hline Personal & $\mathbf{7 7 0}$ & $\mathbf{5 5}$ \\
Naming and self-identification & 726 & 52 \\
Self-appraisal & 44 & 3 \\
\hline Interpersonal relationship & $\mathbf{1 8 9}$ & $\mathbf{1 3 . 4}$ \\
Love relationships & 172 & 12.2 \\
Familial relationships & 17 & 1.2 \\
\hline Philosophical & $\mathbf{1 6 9}$ & $\mathbf{1 2}$ \\
Philosophical perspectives & 88 & 6.2 \\
The ethics of transport & 43 & 3.2 \\
Decline of morals & 38 & 2.6 \\
\hline Religious & $\mathbf{9 1}$ & $\mathbf{6 . 5}$ \\
Expressions of Islamic faith & 38 & 2.7 \\
Supplication & 23 & 1.6 \\
Preaching & 22 & 1.6 \\
Protection from the envious eye & 8 & 0.6 \\
\hline Offensive & $\mathbf{7 7}$ & $\mathbf{5 . 5}$ \\
\hline Political & $\mathbf{6 0}$ & $\mathbf{4 . 3}$ \\
Territorial affiliation & 39 & 2.8 \\
Tribal affiliation & 21 & 1.5 \\
\hline Humorous & $\mathbf{3 8}$ & $\mathbf{2 . 7}$ \\
\hline Sports & $\mathbf{1 6}$ & $\mathbf{0 . 6}$ \\
\hline Total & $\mathbf{1 4 1 0}$ & $\mathbf{1 0 0}$ \\
\hline
\end{tabular}


Table 2 shows that the category of personal graffiti has the highest number $770(55 \%)$ of the data. It seems that the majority of the drivers and passengers show a clear sense of self-concentration, something like: here I am. The second category of interpersonal relationships accounts for $189(13.4 \%)$. This category covers two relationships: familial and love. The third category of philosophical graffiti accounts for $169(12 \%)$. It reflects the drivers' and passengers' philosophical perspectives. It also displays the ethics that should be adhered to while using Jordanian public transport vehicles and immoral behavior people may suffer from or complain about. The fourth category is religious graffiti that accounts for $91(6.5 \%)$. It reflects the official religion of Jordan which is a largely Muslim society. The fifth category of offensive graffiti that accounts for $77(5.5 \%)$. This includes insults aimed at people and hard life conditions. The sixth category of political graffiti accounts for $60(4.3 \%)$. This is about the passengers' and drivers' connection with Jordanian cities and tribes. The seventh category of humor accounts for $38(2.7 \%)$. The passengers and drivers tend to poke fun while criticizing absurdities of both people and societies. The eighth category of sports graffiti accounts for $16(0.6 \%)$. This probably reflects part of the public interest in sports.

Below is a presentation of each communicative category and subcategory followed by an illustrative example. For the reader's convenience, each example is presented in Arabic, transliteration and an English gloss.

\section{Personal graffiti}

This communicative category accounts for 770 (55\%) of the data. It shows how the passengers and drivers identify themselves or others and how they value and appreciate one's quality, conduct, ability, etc. It includes two subcategories, namely, name and self-identification and self-appraisal.

\subsection{Naming and self-identification}

This subcategory accounts for 726 (52\%) of personal graffiti. The passengers and drivers refer to themselves or others by using six patterns of self-identification. These include (a) a person's name or full name without any further self-identification, (b) a name followed by a phone number or an email address, (c) a name followed by the date and/ 
or time of a certain occasion, (d) a name followed by an educational institution's name, (e) a name followed by services and goods offered, and (f) a name followed by a geographical area's name. These patterns were written in Arabic or mixed between Arabic and English. Each pattern is exemplified as follows:

$$
\begin{aligned}
& \text { (1) (a) زيد ابوحميد } \\
& \text { ze:d Pabu ћami:d } \\
& \text { 'Zaid Abu Hameed' }
\end{aligned}
$$

The writer identifies himself or another person by writing the referent's first and surname. The researchers believe that this pattern of self-identification is used to mark one's presence in a place, though vaguely, as there are hundreds of Jordanians who happen to have the same name. MacGillivray and Curwen (2007: 358) maintain that writing one's name in public transport vehicles proves his/her presence in places and achieves great visibility by travelling to different areas.

(b) • vVOVroqry للحلوين فقط مؤيد المحابره

lilhilwi:n faqat muPajjad ilmaha:bra

'0775725926 Muayyad Al-Mahabra for beautiful girls only'

The graffiti writer identifies himself or another person by writing the referent's first and surname followed by a telephone number. The researchers assume that this pattern of self-identification is used to look for friends, socialize, or contact others, particularly beautiful girls. Blume (1985: 145) asserts that people use graffiti to search for contacts in order to overcome isolation.

(c) الخميس 4:15 خريف صويلح 14/11/2019 RAZAN Toqa

raza:n tuqa isswe:lih xari:f lxami:s

'14/11/2019 Razan Tuqaa Suweileh Autumn Thursday 4:15'

The writer writes the first name of two girls, Razan and Tuqaa, followed by some information such as a name of a place (Suweileh: one of the local areas in Amman), a season, a day, a date, and time. It is thought that this pattern of self- identification is used to leave a mark of one's presence on or at a specific mentioned date and place and/ or document the occurrence of a particular occasion in order to be remembered by others after the writers leave buses and/or taxis. Blume (1985: 143) proposes that graffiti acts as diary entries to record notes when addressing any reader. In the same vein, Lapyai (2003: 143) states 
that graffiti functions as a noticeboard used to post messages for the public, provide information, and announce events.

شلة مدرسة الرصيفه للبنات (d) Donia Tsnem Sara Noor Enas dunja tasni:m sa:ra nu:r Pina:s filli madrasit irsajfi lilbana:t 'Donia Tasneem Sara Noor Enas a clique of girls from Rusaifeh Comprehensive School'

The graffiti writer identifies the clique of girls by writing their first names followed by the name of their school. The word filli in Jordanian Spoken Arabic means a group of people who have much in common. The researchers believe that this pattern of identification is used to show that the graffiti writers are attached to their educational institution and that they are highly group-oriented. Blume (1985: 144) demonstrates that "whoever writes the name of a pop-group, a mark of motorbike or something similar as graffiti, proves that he belongs or would like to belong to a group which he regards as prestigious".

علاء الدين السرعه الخارقه للكمبيوتر بيع و صيانه قطع اجزهه 0785849911 (e) ৎal:? iddi:n issurৎa lxa:riqa lilkumbju:tar be:؟ wsija:nit qita؟ Padzhizi

'Aladdin (The Super Speed for Computer) sale and maintenance of parts/machines 0785849911 '

Example 1. (e) is a sticker used to advertise a computer shop named (The Super Speed) which offers services such as maintaining broken computers, selling parts of new computers, and buying used ones. Some owners of properties write business information inside Jordanian public transport vehicles to promote their commercial products and expand work. Graffiti here serves a pragmatic function, something like a text on a billboard advertising goods and promoting business. This coincides with Darwish and Al Rousan (2019: 134) who state that Jordanian business owners often write on vehicles their names followed by services offered, phone numbers, and/or work address to promote business and sell goods. This is less costly than advertising on radio, $\mathrm{TV}$ or in a newspaper and thus can reach a great number of people.

خليل عبادي سلطي (f)

xali:1 Yabba:di salti

'Khalil Abbadi, from Salt'

The graffiti writer identifies himself or another person by writing the referent's first and family name followed by a Jordanian city, 
i.e. Salt. The researchers suggest that writing about geographical areas inside Jordanian public transport vehicles is to express national pride and affiliation to a certain area. This is in line with Lapyai (2003: 142) who claims that graffiti writers express their sense of belonging to places or groups of people when writing about them on/in open spaces. Hazaymeh (2007: 52) comments that Jordanian drivers often write the name of a particular geographical area to express their attachment to it.

\subsection{Self-appraisal}

This subcategory accounts for $44(3 \%)$ of personal graffiti. This shows the drivers' and passengers' sense of value or worth. It displays one's positive evaluation of his/her quality, personality, ability, life achievements, among others. The following is written in blue on a small bus's ceiling:

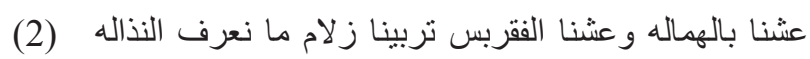

Gifna: bilhama:li whifna: lfagir bas trabbe:na: zla:m ma: niGraf innaða:li

'We were poor and lived the life of a rascal, but we have grown up as men who have not experienced humiliation'

The graffiti writer of example 2 states that he was rascal and outlived harsh conditions yet still perceives himself positively and feels self-worth. He describes himself as an independent and a decent grownup who has never done something disgraceful. Although the word hama:li 'rascality' derogates, the graffiti writer praises himself and is confident of his character. It seems that people are sometimes timid, feel shy, or get embarrassed when praising themselves or saying what they think of others in direct communication. Thus, the researchers propose that people resort to write graffiti inside buses and taxis to express admiration of themselves freely. According to Durmuller (1988: 280281 ), the anonymity of the graffiti writers' identity allows them to voice their thoughts and feelings without restrictions. Hazaymeh (2007: 54) demonstrates that Jordanian drivers write self-evaluative expressions to be acknowledged by other people and show confidence of themselves.

\section{Interpersonal relationship graffiti}

This communicative category accounts for 189 (13.4\%) of the data. Humans are social beings whose feelings of satisfaction, happiness 
and despair are found in relationships. People's social connections with others may result from love, solidarity, friendship, business, etc. This category covers two interpersonal relationships, namely, love and familial.

\subsection{Love relationships}

This subcategory accounts for 172 (12.2\%) of interpersonal relationship graffiti. According to Descartes (cited in Schmitter, 1994: 344), love involves "consent by which we consider ourselves from the present on as joined with which we love, in the sense that we imagine a whole of which we think of ourselves only as one part and the loved thing as another". The passengers and drivers express love through romantic songs, poems, sayings and sketches of hearts or drawings of flowers with lovers' first names or initials. The following example shows agglomerate flames of love that propel the writer to devote what he/she owns to his/her beloved:

$$
\text { لأجلاك تركت الهوى فلا هوى بعد هو الك يهتوى : }
$$

li?adzlik tarakt lhawa: fala: hawa: ba凡d hawa:k juhtawa:

'For you, I have abandoned love; you are my only love'

It seems that the text of this graffiti is borrowed from a poem written by Mansour Al-Hallaj. He is a Persian mystic, a poet and a teacher of Sufism (Encyclopedia Britannica, online). The graffiti writer appears to love someone and hence expresses his sentiment of love to his beloved through a romantic verse. The Jordanian society is generally conservative and has its moral codes and social restrictions on love relationships between strange men and women. Al Ali (2006: 709) explains that greater amounts of privacy is required for women than for men in the Jordanian society in terms of social interactions. They are not supposed to approach men to reveal their love or initiate courtship, and they are expected to remain passive and repress their desires. Men may also be condemned, insulted, or embarrassed if they approach a stranger female and publicly express their love feelings. Therefore, the researchers believe that people write graffiti inside Jordanian public transport vehicles to express love freely and without fear of being rejected, condemned, or disregarded. Some graffiti studies (e.g. Hafez, 2020; Hasrati et al., 2016; Jaradat, 2016) announce that love is a popular theme expressed through romantic expressions, songs, and poetry written on vehicles. 


\subsection{Familial relationships}

This subcategory accounts for 17 (1.2\%) of interpersonal relationship graffiti. The relationship between children and parents in the Jordanian society is reciprocal: children are to be protected and cherished by parents, and they are expected to return complete respect to their parents and be grateful to their caring and help. This mutuallydependent relationship requires cooperative interconnection (Al Hassan and Takash, 2011: 2-3). The following graffiti sheds light on a fatherson/daughter relationship:

(4)

$$
\begin{aligned}
& \text { اذا ابوك عيشك ابوي علمني كيف اعيش }
\end{aligned}
$$

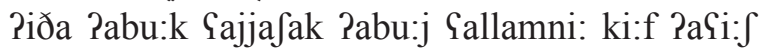

$$
\begin{aligned}
& \text { 'If your father has earned you a living, my father has taught me } \\
& \text { how to earn a living' }
\end{aligned}
$$

The graffiti writer signals his/her acknowledgment of respect to all things offered by his/her father by describing what kind of relationship he/she has with his/her father. The writer's father has taught him/her how to be self-sufficient by putting him/her on the right track to build his /her life track independently. The writer's father has taught him/ her how to earn a living instead of living at the expense of others. The Jordanian society, as many others, considers family a basic social unit and the relationship between children and parents a significant familial interaction. Parents generally put great efforts to raise their children to grow up, and children are assumed to learn that the interests of their families come first and that showing respect to their parents is a must. The researchers think that the passengers' and drivers' graffiti about familial relationships inside Jordanian public vehicles here shows gratitude for and appreciation of their parents' efforts and sacrifice. Hazaymeh (2007: 47) states that Jordanian drivers express the importance of their families by protecting them from danger and by writing about the positive influence of families on one's life.

\section{Philosophical graffiti}

This communicative category accounts for $169(12 \%)$ of the data. Philosophy includes inquiries about the nature of the universe, reality, and knowledge; it addresses ethics, morals and social interactions. It also displays views or activities used to understand the nature of death, life, luck, destiny, existence, etc. (Palma, 1991: 41). There are 
three subcategories, namely, philosophical perspectives, the ethics of transport, and decline of morals.

\subsection{Philosophical perspectives}

This subcategory accounts for 88 (6.2\%) of philosophical graffiti. This includes the passengers' and drivers' philosophical views about social relationships, life, dream, future, etc. The following is written in black on the ceiling of a large bus:

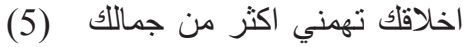

Paxla:qak tahummuni: PakӨar min dzama:lak

'Your manners matter to me more than your beauty'

While many think that beauty comes first, the writer believes that manners matter more than beauty. People acquire philosophy from families, friends, news and media, books, lyrics, and life experience, among others. They often undergo personal experiences and make observations and deductions. Their philosophical perspectives might carry moral lessons, advice, grudges and truths. Therefore, the researchers propose that the passengers' and drivers' writing about philosophical experiences inside Jordanian public transport vehicles might turn to be an effective way to disseminate knowledge and wisdom among people. This resonates with D'Angelo (1974: 173) who maintains that philosophical graffiti carries moral and ethical truths "created by individuals but placed into circulations by the masses".

\subsection{The ethics of transport}

This subcategory accounts for 43 (3.2\%) of philosophical graffiti. Ethics, also called moral philosophy, is "the philosophical study of moral judgements which are value judgements about what is virtuous or base, just or unjust, morally right or wrong, morally good or bad or evil, morally proper or improper" (Oladipo \& Akinsanya, 2006: 26). This includes principles that the passengers need to adhere to when using Jordanian public transport vehicles. Some principles are common and seen on the walls of public places such as hospitals. They are about keeping places clean and prohibiting smoking. However, there are principles related to how the passengers should behave when using public transport vehicles. The following is written on the passenger's seat of a yellow taxi: 


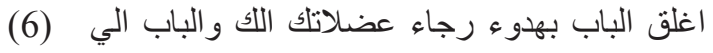

Piyliq lba:b bihudu:? radza:Pan Gadala:tak Pilak wlba:b Pili

'Shut the door quietly, please. Muscles are yours but the door is mine'

The taxi driver asks male passengers to shut the door of his vehicle softly. The word Sadala:tak 'your muscles' is used to remind them that there is no need to shut the door violently. According to Stern and Solomon (1992: 169), vehicles are "powerful symbols that express cultural values such as power, freedom, materialism, success and individualism". Therefore, some drivers try to keep them new. The researchers assume that ethical rules are written to inform the passengers about the right manners and principles they should adhere to while using Jordanian public transport vehicles. For examples, adhering to the principles that prohibit distracting the drivers while driving may guarantee the safety of the public.

\subsection{Decline of morals}

This subcategory accounts for $38(2.6 \%)$ of philosophical graffiti. One of the greatest challenges in today's society is when a person's character or action is not in line with the admirable traits or code of conduct agreed upon by one's society or profession. People generally suffer from immoral behavior such as cheating because it damages relationships and hurts feelings. While trust is a valued moral, betrayal would open the door to exploitation, emotional damages, and charged feelings of anger (Divsalar \& Nemati, 2012: 364). The driver's frustration as a result of his beloved's betrayal is exemplified in the following graffiti written on the sun visor of a small bus:

عدوك يرحم بحالك واعز احباب يخونك (7) عaل)

Gaduwwak jirham biha:lak w?a؟az Pahba:b jixunak

'Your enemy has mercy on you, and your dearest betrays you'

It appears that the text of this graffiti is borrowed from the lyrics of a song titled $\boldsymbol{l a} \boldsymbol{j} \boldsymbol{a}$ s $\boldsymbol{a} \boldsymbol{a d i}$ :qi. It seems that the driver is distressed and resentful for trusting the wrong people. He compares between his dearest and enemies in terms of morals. His dearest has let him down and betrayed his trust while his enemy has been merciful to him. The researchers suggest that people's graffiti written inside Jordanian public transport vehicles show their dismay by, disappointment of, and anxieties about decline of morals witnessed around. Divsalar and Nemati 
(2012: 371) point out that writing on vehicles about immoral behavior such as betrayal may improve good morals by showing what social troubles or emotional damages one may suffer from when betrayed.

\section{Religious graffiti}

This communicative category accounts for $91(6.5 \%)$ of the data. Religious graffiti written inside Jordanian public transport vehicles is Islamic in nature and reflects the official religion of Jordan which is a largely Muslim society (Britannica Encyclopedia, online). Islamic graffiti tokens often appear as an announcement of religious affiliation. Faniran et al. (2019: 118-119) demonstrate that adherents of a certain religion write religious texts on vehicles to express their total allegiance to that religion, identify their faith, and propagate ideas to the public. Some graffiti studies (e.g. El-Nashar \& Nayef, 2016; Hafez, 2020; Hazaymeh, 2007) point out that religion, particularly Islam, is a common theme expressed through Qur'anic verses, Hadith, and other religious expressions written on vehicles. There are four subcategories, viz., expressions of Islamic faith, supplication, preaching, and protection from the envious eye.

\subsection{Expressions of Islamic faith}

Religious graffiti falls under this subcategory that accounts for 38 (2.7\%). Many Muslims express their commitment to Islam and renew faith in their hearts and minds through Quranic verses, Hadith, and religious expressions (El-Nashar \& Nayef, 2016: 230). It is noticed that passengers and drivers alike use different manners to show their Islamic faith, viz., (a) testimony of faith in Islam, (b) Islamic remembrance, and (c) personal sentiments.

The testimony of faith in Islam is called affaha:da, and it is the first of the five pillars of Islam. Through this testimony, Muslims affirm a sincere belief in the oneness of Allah. They also affirm that Prophet Muhammad is His servant and messenger (Asni, 2017: 347). The testimony of faith in Islam through affaha:da occurs many times inside Jordanian public transport vehicles.

اشهُ ان لا اله الا الله وان محمد رسول الله (8) التان

Pafhadu Pan la: Pila:ha Pilla lla:h wa Panna muћammadan rasu:lu lla:h

'I testify that there is no god worthy of worship except for Allah and that Muhammad is His prophet' 
The second manner is Islamic remembrance. This is about ritual prayers performed by Muslims individually or collectively, silently or aloud, to glorify and praise Allah (El-Nashar \& Nayef, 2016: 232). They often involve repeating one of Allah's good names (of which there are 99 names, according to the Isalmic religion) and direct quotations from Qur'an and Hadith as in

لا اله الا انت سبحانك إني كنت من الظالمين (9) (9)

la: Pila:ha Pilla Pant subha:nak Pinni: kuntu mina $\underline{\partial ð a}$ :limi:n

'There is no god but Allah, glory to you! I have been indeed among the wrongdoers'

In this prayer, it is believed that there is no Allah but Him, that all life matters are controlled by the will of Allah rather than human beings and that Muslims are among the wrongdoers. Reciting prayers shows Muslims' gratitude to Allah and acknowledgment of His majesty and keeps them connected to Him in times of distress and happiness (Geels, 1996: 56).

The third manner is personal sentiments. They are individuals' thoughts and feelings reflected in dialogic statements with Allah or His Prophet as in

$$
\begin{aligned}
& \text { احبك يا رسول الله } \\
& \text { Puhibbuk ja: rasu:1 lla:h } \\
& \text { 'I love you O' Messenger of Allah }
\end{aligned}
$$

In the text of this graffiti, the writer expresses his/her love to Prophet Mohammad. Muhammad's teachings and life set an example which Muslims should follow (Hazaymeh, 2007: 33).

\subsection{Supplication}

This communicative subcategory accounts for $23(1.6 \%)$ of religious graffiti. In the terminology of Islam, supplication is duca:? and refers to Muslims' invocations and personal appeals of their desires, needs and anxieties to Allah. Supplications can be done silently or loudly in private or public sermons (Aydin, 2013: 3-4). The passengers and drivers have supplicated Allah for mercy, forgiveness, cure from diseases, etc. The following clarifies this subcategory:

$$
\text { أستودعك الله الذي لا تضيع ودائعه }
$$

PastawdiGuka lla:h illadxi la: tadi:

'I entrust Allah with you; $\mathrm{He}$ is with Whom trust is never misplaced' 
In the text of this graffiti, Muslims show their dependence on Allah in attaining their interests, pushing harm away, and caring about life matters. This is derived from the belief that all life details such as age, wealth, happiness, sadness, health, and the like are under Allah's control. It appears that Muslims feel safe when placing all matters in Allah's trust since His trust is never misplaced (Al Munajjid, 2014: 7-8). Banikalef (2019: 409) reports that invoking Allah's names and supplications abound among Jordanians. These practices are a direct result of the impact of Islam on the speech of Muslims, in general, and on the speech of Jordanians, in particular.

\subsection{Preaching}

This communicative subcategory accounts for $22(1.6 \%)$ of religious graffiti. Preaching in Islam refers to any form of persuasion used to change people's attitudes and minds to comply with the commands and rulings of Allah as brought by Prophet Muhammad. It also aims at conveying information about Islam by Muslim preachers or communicators to fulfill objectives that comply with the holy Qur'an and Al-Sunnah (Husin, 2014: 35). Some graffiti writers have preached about the need for asking forgiveness from Allah and saying prayers for Prophet Mohammad.

$$
\begin{aligned}
& \text { انت با شب غض بصرك } 10 \\
& \text { Pinta ja: Jab yud basarak } \\
& \text { 'You guy! Avert your gaze' }
\end{aligned}
$$

The writer commands men not to look at girls in the bus. Muslims are generally aware of the Quranic and Hadith injunctions to lower their gaze from members of the opposite sex, especially when there is a desire or an attraction. By averting one's gaze, one can guard his/ her modesty and chastity and avoid arousing sexual passions (Akhter \& Munir, 2017: 11).

\subsection{Protection from the envious eye}

This communicative subcategory accounts for $8(0.6 \%)$ of religious graffiti. Like many societies, the belief in the envious eye in the Jordanian society is constantly present, alongside the belief in spirits and jinns, which affects how people perceive the world. The envious eye is associated with envy that refers to the wish that the 
rewards and blessings bestowed to some people by Allah vanish. People generally envy others or things when looking, touching or verbally expressing excessive praise without a blessing. It is believed that envy causes impairment, sterility, unemployment, failure in marriage and relationships, sickness, among others. The common Arabic word for the envious eye is $\boldsymbol{e} \boldsymbol{e} \boldsymbol{n}$ (Abu Rabia, 2005: 241-242). The following sheds light on how one of the passengers perceives the envious eye:

العين صابتني ورب العرش نجاني عين الحسود فيها عود

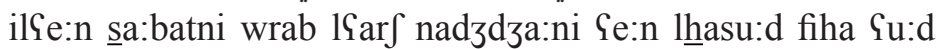

'I was envied and the Lord of the Throne saved me. May the envious eye be poked'

In the text of this graffiti, the writer indicates that he/she is envied and that Allah has helped protect him/her against the envious eye. A palm-shaped amulet is drawn next to this text. Throughout the Middle East, this drawing is generally used to defeat the envious eye (Abu Rabia, 2005: 245-246). It is argued that writing about the envious eye inside Jordanian public transport vehicles might be traced to the passengers' and drivers' fear and discomfort of its negative effects. Jaradat (2016) and Darwish and Al Rousan (2019) posit that Jordanian drivers have expressed their concern and fear of the envious eye by writing Qur'anic verses whose aim is to protect them from such an eye.

\section{Offensive graffiti}

This communicative category accounts for 77 (5.5\%) of the data. The passengers and drivers tend to expose their anger, hostility, and frustration through offensive and derogatory expressions. Some graffiti tokens show insults aimed at individuals, groups of people, or hard life conditions. In the following, the writer offends a woman, for he/she is shocked and disappointed by the disruption of expectations as to how the other should behave:

$$
\text { فكرتك شريفه طلعت شلف }
$$

fakkartik Jari:fi tlisti Jalaf

'I thought you were well-behaved, but you turned out to be a whore'

The writer insults and offends publicly. It is stated that a particular woman is thought to be well-behaved yet turns out to be a whore. The word falaf in Jordanian Spoken Arabic describes a woman who has 
many sexual partners in her life. Since the graffiti writers' identity is anonymous, the researchers assume that they are offered an opportunity to express feelings of hostility, anger and frustration without the need to face the consequences of these feelings as would be the case with direct communication. This is in line with Blume (1985: 142), who argues that the lack of social connection between graffiti writers and readers may explain why insults and taboo themes are treated without restriction in the discourse of graffiti.

\section{زمن اخو شرموطه (15) zaman Paxu Jarmu:ta \\ 'Life is a bitch'}

The writer seems to be furious and angry because of life's sufferings. He/she describes life as farmu:ța which means a 'bitch' in Jordanian Spoken Arabic. The researchers claim that offensive graffiti written inside Jordanian public transport vehicles reveals people's discontent with, anxieties about, and dissatisfaction with hard living conditions. Fraser (1980: 258-260) claims that graffiti helps "vent frustrations, to say things you wouldn't dare speak up about ... because sometimes you feel like letting the whole world know how you're feeling w/out [without] giving yourself away".

\section{Political graffiti}

This communicative category accounts for 60 (4.3\%) of the data. Politics occupies the thoughts of many Jordanians because of the political crisis and changes in the Middle East. Like other societies, the Jordanian society is a mixture of opponents and proponents of political decisions and policies. This category is found to be free of hatred for, or political conflict with, Jordanian policies, and is rather about the passengers' and drivers' affiliation with Jordanian cities and tribes.

\subsection{Territorial affiliation}

This subcategory accounts for $39(2.8 \%)$ of political graffiti. People are attached either personally or collectively to their localities ranging from villages, towns, cities, or nations (Knight, 1982: 515). Some passengers and drivers express their affiliation to their homeland Jordan and its Hashemite leadership by writing about what Jordanian cities mean to them. 
صحيح حب السلط ما بطعمي خبز بس اقسم بالله بشبعك كرامه

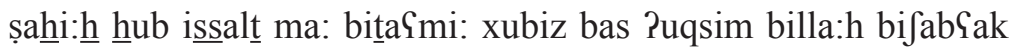
kara:mi

'It is true that loving Salt does not serve the basic needs, but I swear to Allah that it overwhelms you with dignity'

Example 16 is a sticker stuck on the glove compartment of a service taxi. The graffiti writer states that that he/she loves Salt, a city in west-central Jordan, despite his/her poor economic hardships. He/ she acknowledges the fact that this kind of love does not satisfy his/her basic needs of living but promotes dignity. This text reflects Jordanians' determination to handle any economic, political, or social burden for the sake of their homeland. The researchers believe that feelings of national pride, glory and love motivate the passengers and drivers to write about Jordanian cities inside Jordanian public transport vehicles. This resonates with Hazaymeh (2007: 47-48) who maintains that Jordanian drivers write the names of Jordanian areas on buses and taxis to show attachment to these areas.

\subsection{Tribal affiliation}

This subcategory accounts for $21(1.5 \%)$ of political graffiti. The structure of the Jordanian society is a tribal one. It has big and small tribes that live next to each other in Jordanian deserts and other areas. A tribe is a loosely knit group of individuals who have a hereditary political unit and a social system based on equality, harmony, and cooperation (Banikalef, 2019: 409). This type of affiliation is seen in this example.

هذا العالم يحتاج الى الكثيرمن القيسييه ليصبح رائعا

hada: 14a:lam jahta:dz Pila lkaӨi:r min lqe:sijji lijusbih ra:Piৎan

'This world needs a lot of Qaisiyyi to be great'

The graffiti writer expresses how he/she is deeply linked to and proud of his/her Jordanian tribe, Qaisiyyi, by considering it the magical wand needed to make a wonderful world. He/she implies that the world is miserable, and it is his/her tribe that will make it great. Feelings of belonging to a group of people can provide security against threats, as well as power and status; as such, they may have promoted the passengers and drivers to write about their tirbes inside Jordanian public transport vehicles. Jordanian tribes are effective socio-political institutions that have their weight and influence on the 
political, economic, and social aspects the Jordanian society (Banikalef, 2019: 410). Darwish and Al Rousan (2019: 135) maintain that writing Jordanian tribes' names on vehicles signals drivers' belonging to the tribes and the community at large.

\section{Humorous graffiti}

This communicative category accounts for $38(2.7 \%)$ of the data. Humor is a universal phenomenon that most people experience in many contexts. According to Lynch (2002: 423), humor is an "intended or unintended message interpreted as funny". In this definition, humor is a matter of subjectivity. What is funny and humorous in a culture may not be the same in other cultures. Meyer (2000: 311) argues that much humor is situationally dependent. However, even if humor fails to make someone laugh, it is still an attempt to evoke hilarious responses. This category includes simple, comical, and light-hearted messages that rely on satire to ridicule people's foibles and societal ills. Bamidele (2001: 32) refers to satire as "the art of laughter with knives". Satirists often use laughter as a weapon to persuade people that something is reprehensible or ridiculous, and hence they need to follow moral standards. Some passengers and drivers attempt to poke fun while criticizing absurdities of individuals, a class of people, or societies.

اشلح من اجرك بلاش توسخ الأرضيية

Piflah min Pidzrak bala:S twassix 1Pardijji

'Take your shoes off to keep the floor clean'

Example 18 is written in black on the stairs of a small bus. The writer orders the passengers to take off their shoes to keep the floor of the bus clean. In fact, taking off one's shoes before getting to a bus would be awkward and violate the rules of transportation; however, people generally take off their shoes before entering a house. It would seem that the writer is sending a message about cleanliness to the passengers, in a humorous way: the bus is clean and thus do not litter.

السعاده مثل الباله لقطات

issaSa:di miӨil lba:li laqta:t

'Happiness is like secondhand clothes, which are a lucky find'

This graffiti token appears many times in different vehicles. It carries a bitter and harsh criticism of life conditions. The graffiti writer 
compares happiness to new clothes rarely found in secondhand shops. This is to imply that finding happiness amid all troubles and obstacles is a matter of luck. The comparison might be funny and drag a smile, but it is a clear ridicule of people's living. This may arouse contempt in the audience for their own sufferings. The researchers suggest that the passengers and drivers leave satirical graffiti inside Jordanian public transport vehicles to discredit people, expose their foibles, and criticize absurdities of the societies. Meyer (2000: 320) claims that satirical humor is used to highlight deviant social norms that need correction.

\section{Sports graffiti}

This communicative category accounts for $16(0.6 \%)$ of the data. Sports is a widely-known phenomenon spread all over the world and occupies the thinking of most young generations. Football is one of the most popular sports in Jordan (Hazaymeh, 2007: 48-49). One of the successful leading football teams in Jordan's history is Al-Faisaly club. Some passengers and drivers show support to this team.

\section{الفيصلي اجمل بكثير من ذللك المدعو بالحب}

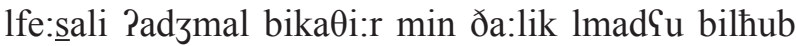
'Faisaly is much more beautiful than love'

Example 20 is a sticker stuck on the glove compartment of a yellow taxi. The writer considers his football team much more beautiful than love. The researchers assume that sports graffiti show passengers' and drivers' interest in, fondness of, and support to their favorite teams. This is in line with Hazaymeh (2007: 48) who contends that Jordanian drivers express their devotion and loyalty to their favorite football teams by writing their names, scores and victories.

\section{Conclusion and Recommendation}

The study reported here has investigated the communicative categories and subcategories of graffiti written inside Jordanian public transport vehicles. The analysis has shown eight communicative categories and thirteen subcategories. The eight communicative categories are: personal, interpersonal, philosophical, religious, offensive, political, humorous, and sports. The thirteen subcategories are: naming and self-identification, self-appraisal, love and familial relationships, 
philosophical perspectives, the ethics of transport, decline of morals, expressions of Islamic faith, supplication, preaches, protection from the envious eye, territorial and tribal affiliation. The study concludes that language consciousness of ordinary people is clearly displayed in the discourse of graffiti. Moreover, societal concerns and individuals' feelings as embodied in graffiti are transmitted through different communicative categories and subcategories. The passengers and drivers have expressed their self-concentration, philosophical perspectives, affiliation to territories and tribes, hostility and anger to individuals and groups, allegiance to Islamic religion, and interests in sports. The findings also highlight that there are socio-psychological motives that drive writing graffiti, viz., identify oneself, release emotions, criticize individuals and groups, show pride and admiration, advertise goods and promote business, search for contacts, post messages for the public, express attachment to educational institutions and sports teams, document the occurrence of a particular occasion, etc.

The study recommends that graffiti written inside public transport vehicles in other Arab countries be examined. Thus, one could examine to what extent the communicative categories and subcategories of graffiti vary from one country to another. Future research may also look into pictorial graffiti with a view to analyzing their communicative themes and socio-psychological motives.

\section{Acknowledgement}

We would like to thank the owners, drivers, and conductors of public transport vehicles whose informed consent enabled the authors to collect the relevant data from their vehicles.

\section{References}

Abu Rabia, A. (2005). The evil eye and cultural beliefs among the Bedouin tribes of the Negev, Middle East. Folklore, 116, 241-254. Doi10.1080/ https://doi. org/10.1080/00155870500282677

Akhter, N., \& Munir, A. (2017). Hijab (veil): Protection for woman (Islamic perspective) international conference on Arabic studies and Islamic civilization. In E-Proceedings of the $4^{\text {th }}$ International Conference on Arabic Studies and

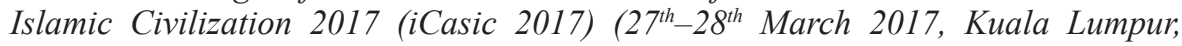
Malaysia). (Vol. 4, pp. 9-17). URL: http://WorldConferences.net 
Al Ali, M. (2006). Religious affiliations and masculine power in Jordanian wedding invitation genre. Discourse and Society, 17(6), 691-714. https://doi. org/10.1177/0957926506068428

Al Hassan, S., \& Takash, H. (2011). Attributions and attitudes of mothers and fathers in Jordan. Parenting: Science and Practice, 11(2-3), 142-151. https://doi.org/10. 1080/15295192.2011.585559

Al Munajjid, Z. (2014), Reliance on Allah. Zad Group.

Alkurdi, K. (2016). A linguistic study of the graffiti written on the means of transportation in Jordan [Unpublished M.A Thesis]. Jadara University.

Asni, F. (2017). Analysis of the concept of two kalima shahadah al-tauhid and al-risalah according to the Qur'an and al-hadith. International Journal of Academic Research in Business and Social Sciences, 7(10), 374-353. https://doi. org/10.6007/IJARBSS/v7-i10/3383

Aydin, H. (2013). Supplication, prayer and their [sic] inner peace they afford. The Journal of Rotterdam Islamic and Social Sciences, 4(1), 1-11. https://doi. org/10.2478/jriss-2014-0005

Bamidele, O. (2001). Comedy: Essays and studies. Stirling-Horden Publishers Ltd.

Banikalef, A. (2019). The impact of culture and gender on the production of online speech acts among Jordanian facebook users. International Journal of ArabicEnglish Studies, 19(2), 399-414. https://doi.org/10.33806/ijaes2000.19.2.9

Blume, R. (1985). Graffiti. In T.A. van Dijk (Ed.), Discourse and literature: New approaches to the analysis of literary genres (pp. 137-148). John Benjamins Publishing Company. https://doi.org/10.1075/ct.3.09blu

Case, C. (1992). Bumper stickers and car signs: Ideology and identity. Journal of Popular Culture, 26(3), 107-119. https://doi.org/10.1111/j.00223840.1992.2603_107.x

D'Angelo, F. (1974). Sacred cows make great hamburgers: The rhetoric of graffiti. College Composition and Communication, 25(2), 173-180. https://doi. org/10.2307/357170

Darwish, I., \& Al Rousan, R. (2019). Words on wheels: Investigating car inscriptions in Jordan. Journal of Educational and Social Research, 9(4), 128-137. https:// doi.org/10.36941/jesr-2019-0015

Date-Bah, E. (1980). The inscriptions on the vehicles of Ghanaian commercial drivers: A sociological analysis. The Journal of Modern African Studies, 18(3), 525-531. https://doi.org/10.1017/S0022278X00011642

Divsalar, F., \& Nemati, A. (2012). Social pathology of trust in car written manuscripts. Mediterranean Journal of Social Sciences, 3(3), 363-372.

Durmuller, U. (1988). Research on mural spray scripts (Graffiti). In A.R. Thomas (Ed.), Methods in Dialectology (pp. 278-284). Multilingual Matters Ltd.

El-Nashar, M., \& Nayef, H. (2016). Discourse on the go: Thematic analysis of vehicle graffiti on the roads of Egypt. Advances in Language and Literary Studies, 7(5), 227-239. https://doi.org/10.7575/aiac.alls.v.7n.5p.227

Elo, S., \& Kyngäs, H. (2008). The qualitative content analysis process. Advanced Nursing, 62(1), 107-115. https://doi.org/10.1111/j.1365-2648.2007.04569.x

Encyclopedia Britannica (n.d.). URL: https://www.britannica.com/

Faniran, O., Ikotun, R., \& Oloyede, A. (2019). The utilitarian functions and the nature of vehicle inscriptions and stickers in Southwestern Nigeria. Journal of Language and Literature, 19(2), 108-125. https://doi.org/10.24071/joll.v19i2.2141 
Fraser, B. (1980). Meta-Graffiti. Maledicta: The International Journal of Verbal Aggression, 4, 258-260.

Geels, A. (1996). A note on the psychology of dhikr: The halveti-jerrahi order of dervishes in Istanbul. International Journal for the Psychology of Religion, 6(4), 229-251. https://doi.org/10.1207/s15327582ijpr0604_1

Gleitman, L., \& Papafragou, A. (2005). Language and thought. In K.J. Holyoak, \& R.G. Morrison (Eds.), The Cambridge Handbook of Thinking and Reasoning (pp. 633-661). Cambridge University Press.

Hafez, O. (2020). Moving discourse: Egyptian bumper stickers as a communicative event. International Journal of Linguistics, Literature and Translation, 3(9), 2640. https://doi.org/10.32996/ijllt.2020.3.9.4

Hasrati, M., Street, B., \& Habibi, S. (2016). Vehicle writings in an Iranian context: The interplay of habitus and field. Iranian Studies, 49(1), 1-27. https://doi.org/10 $.1080 / 00210862.2014 .936149$

Hazaymeh, W. (2007). A sociolinguistic study of written expressions on vehicles in Jordan [Unpublished M.A Thesis]. Yarmouk University.

Husin, S. (2014). The importance and roles of linguistics in Islamic studies: Integration of linguistics with religious studies. Khazanah, 12(1), 28-37. https:// doi.org/10.18592/khazanah.v12i1.299

Jaradat, A. (2016). Content-based analysis of bumper stickers in Jordan. Advances in Language and Literary Studies, 7(6), 253-261. https://doi.org/10.7575/aiac. alls.v.7n.6p. 253

Knight, B. (1982). Identity and territory: Geographical perspectives on nationalism and regionalism. Annals of the Association of the American Geographers, 72(4), 514531. https://doi.org/10.1111/j.1467-8306.1982.tb01842.x

Lapidus, I. (1997). Islamic revival and modernity: The contemporary movements and the historical paradigms. Journal of the Economic and Social History of the Orient, 40(4), 444-460. https://doi.org/10.1163/1568520972601486

Lapyai, S. (2003). Scratching protest: A study of graffiti as communication in universities in Thailand [Unpublished Doctoral Thesis]. Edith Cowan University.

Lynch, O. (2002). Humorous communication: Finding a place for humor in communication research. Communication Theory, 12(4), 423-445. https://doi. org/10.1111/j.1468-2885.2002.tb00277.x

MacGillivray, L., \& Curwen, M. (2007). Tagging as a social literacy practice. Journal of Adolescent and Adult Literacy, 50(5), 354-369. https://doi.org/10.1598/ JAAL.50.5.3

Meyer, J. (2000). Humor as a double-edged sword: Four functions of humor in communication. Communication Theory, 10(3), 310-331. https://doi. org/10.1111/j.1468-2885.2000.tb00194.x

Mostafa, R. (2018). Online newspapers portrayal of Arab female athletes in Rio 2016 Olympics: A multimodal critical discourse analysis. International Journal of Arabic-English Studies, 18, 49-70.

Oladipo, O., \& Akinsanya, P. (2006). Philosophy and Logic. Hope Publications Ltd.

Palma, A. (1991). Philosophizing. Philosophy, 66(255), 41-51. https://doi.org/10.1017/ S0031819100052839

Schmitter, A. (1994). Representation, self-representation, and the passions in Descartes. The Review of Metaphysics, 48(2), 331-357. 
Sechrest, L., \& Flores, L. (1969). Homosexuality in the Philippines and the United States: The handwriting on the wall. The Journal of Social Psychology, 79(1), 3-12. https://doi.org/10.1080/00224545.1969.9922380

Stern, B., \& Solomon, M. (1992). Have you kissed your professor today? Bumper stickers and consumer self-statements. Advances in Consumer Research, 19, 169-173.

Taylor, C. (1999). Organizational graffiti: A different approach to uncovering issues. Journal of Management Education, 23(3), 290-296. https://doi. org/10.1177/105256299902300305

Wardhaugh, R. (2006). An introduction to sociolinguistics. (6 $6^{\text {th }}$ ed.). Wiley-Blackwell.

\section{АНОТАЦІЯ}

Мета. Вивчити найпоширеніші комунікативні категорії та підкатегорії графіті, зображені всередині транспортних засобів громадського транспорту Йорданії. Методи. Дослідники зібрали 1410 графіті з шести йорданських міст: Аммана, Мадаби, Ірбіда, Зарки, Солта та Джераша. Дані, зібрані у громадському транспорті, включали 1000 рукописних графіті та 410 наклейок, зроблених на замовлення. Зокрема, дані були зібрані з великих та малих автобусів, а також службових та жовтих таксі, які вишикувалися в ряд на головних автобусних станціях та автобусних зупинках, розташованих перед лікарнями, університетами, торговими центрами та поряд із транспортними кільцями. Потім були визначені категорії та підкатегорії графіті на основі їхнього змісту. Результати. Аналіз виявив вісім комунікативних категорій, а саме: особистісні, міжособистісні, філософрські, релігійні, образливі, політичні, гумористичні та спортивні. Аналіз також виявив тринадиять підкатегорій: найменування i самоідентифрікація, самооцінка, любов і сімейні відносини, філософські погляди, етика транспорту, падіння моральності, вираження ісламської віри, благання, проповіді, захист від заздрісних очей, територіальна та племенна приналежність.

Висновки. Дослідження дозволяє зробити висновок про те, що безліч суспільних проблем, а також почуття та думки окремих людей передаються через дискурс графіті. Пасажири та водії висловлюють свою зосередженість на собі, виражають філософські погляди, приналежність до територій та племен, ворожість та гнів до окремих людей та груп, вірність релігійним переконанням та традиціям. Дослідження також дало змогу зробити висновок, що існують сочіально-психологічні мотиви, які спонукають писати графріті, а саме: самоідентифікація, виплеск емочій, критика окремих осіб та груп, гордість та захоплення, реклама товарів та просування бізнесу, пошук контактів, розміщення повідомлень для громадськості, вираз прихильності до навчальних закладів, документування подій. Дослідження рекомендує вивчити графіті, написані всередині транспортних засобів громадського транспорту інших арабських країнах. Так можна вивчити, якою мірою комунікативні категорії та підкатегорії графіті, а також їх соціально-психологічні тенденції мають загальноарабську основу. 
Ключові слова: категорія, графіті, міжособистісні стосунки, психолінгвістика, релігія, самоконцентрація.

\title{
Аль Каразоун А. Гхада \& Хамдан М. Джихад. Граффити в общественном транспорте Иордании
}

\begin{abstract}
АННОТАЦИЯ
Цель. Изучить наиболее распространенные коммуникативные категории и подкатегории граффити, написанных внутри транспортных средств общественного транспорта Иордании.
\end{abstract}

Методы. Исследователи собрали 1410 графрити из шести иорданских городов: Аммана, Мадабы, Ирбида, Зарки, Солта и Джераша. Данные, собранные в общественном транспорте, включали 1000 рукописных графрити и 410 наклеек, сделанных на заказ. В частности, данные были собраны с больших и малых автобусов, а также служебных и желтых такси, которые выстроились в ряд на главных автобусных станциях и автобусных остановках, расположенных перед больницами, университетами, торговыми центрами и рядом с транспортными кольцами. Затем были определены категории и подкатегории графрфити на основе их содержания.

Результаты. Анализ выявил восемь коммуникативных категорий, а именно: личные, межличностные, философские, религиозные, оскорбительные, политические, юмористические и спортивные. Анализ также выявил тринадцать подкатегорий: именование и самоидентификация, самооценка, любовь и семейные отношения, философские взгляды, этика транспорта, падение нравов, выражение исламской веры, мольбы, проповеди, защита от завистливых глаз, территориальная и племенная принадлежность.

Выводы. Исследование позволяет сделать вывод о том, что множество общественных проблем, а также чувства и мысли отдельных людей передаются через дискурс граффити. Пассажиры и водители выражают свою сосредоточенность на себе, философские взгляды, принадлежность к территориям и племенам, враждебность и гнев к отдельным людям и группам, верность религиозным убеждениям и традициям. Также выявлено, что существуют социально-психологические мотивы, побуждающие писать граффити, а именно: самоидентификация, выплескивание эмоций, критика отдельных лиц и групп, гордость и восхищение, реклама товаров и продвижение бизнеса, поиск контактов, размещение сообщений для общественности, выражение привязанности к учебным заведениям, документирование события. Исследование рекомендует изучить граффити, написанные внутри транспортных средств общественного транспорта в других арабских странах. Таким образом, можно изучить, в какой степени коммуникативные категории и подкатегории граффити, а также их социально-психологические тенденции имеют общеарабскую основу.

Ключевые слова: категория, граффити, межличностные отношения, психолингвистика, религия, самоконцентрация. 